Original Research Paper

\title{
Investigation of the Photoheterotrophic Hydrogen Production of Rhodobacter sphaeroides KCTC 1434 using Volatile Fatty Acids under Argon and Nitrogen Headspace
}

\author{
${ }^{1}$ Ruby Lynn G. Ventura, ${ }^{2}$ Jey-R S. Ventura and ${ }^{1}$ Young-Sook Oh \\ ${ }^{1}$ Department of Environmental Engineering and Energy, Myongji University, \\ 116 Myongji-Ro, Cheoin-Gu, Yongin, Gyeonggi-Do 449-728, Republic of Korea \\ ${ }^{2}$ Department of Engineering Science, College of Engineering and Agro-Industrial Technology, \\ University of the Philippines Los Baños, College, 4031 Los Baños, Laguna, Philippines
}

\author{
Article history \\ Received: 12-09-2016 \\ Revised: $12-10-2016$ \\ Accepted: 25-11-2016 \\ Corresponding Author: \\ Ruby Lynn G. Ventura \\ Department of Environmental \\ Engineering and Energy, \\ Myongji University, 116 \\ Myongji-Ro, Cheoin-Gu, \\ Yongin, Gyeonggi-Do 449- \\ 728 , Republic of Korea \\ Tel : +63-935-432-0510 \\ E-mail: rubylynng@gmail.com
}

\section{Introduction}

In the recent years, the issue of energy security and environmental pollution has gained considerable attention. Various scientific endeavors have been directed at generating petroleum-independent and low-carbon technologies as the global industry hopes to transition to a sustainable bio-based economy (Golden and Handfield, 2014; Lee, 2016). $\mathrm{H}_{2}$ has been known as a clean and renewable energy carrier, a promising alternative to fossil fuels. It does not evolve $\mathrm{CO}_{2}$ during combustion and has an energy yield (122 $\mathrm{kJ} / \mathrm{g}$ ) that is 2.75 times greater than any hydrocarbon fuels (Kapdan and Kargi, 2006). A more cost-effective, energy efficient and ecologically benign means of $\mathrm{H}_{2}$

\begin{abstract}
In this study, the photo fermentative $\mathrm{H}_{2}$ production of Rhodobacter sphaeroides KCTC 1434 was investigated using acetate, propionate and butyrate under argon and nitrogen headspace gases. The in $\mathrm{H}_{2}$ yield and Substrate Conversion Efficiency (SCE) were observed from butyrate $\left(8.84 \mathrm{~mol} \mathrm{H}_{2} / \mathrm{mol}\right.$ butyrate consumed, $\left.88.42 \% \mathrm{SCE}\right)$ and propionate $\left(6.10 \mathrm{~mol} \mathrm{H}_{2} / \mathrm{mol}\right.$ propionate consumed, $\left.87.16 \% \mathrm{SCE}\right)$ under $\mathrm{Ar}$ headspace. Utilization of acetate was associated with low $\mathrm{H}_{2}$ evolution, igh yield and high final $\mathrm{pH}$, which suggest that acetate uptake by the strain involves a biosynthetic pathway that competes with $\mathrm{H}_{2}$ production. The use of $\mathrm{N}_{2}$ in sparging resulted to a decreased $\mathrm{H}_{2}$ SCE) and butyrate ( $1.22 \mathrm{~mol} \mathrm{H}_{2} / \mathrm{mol}$ butyrate consumed, $\left.1.04 \% \mathrm{SCE}\right)$ and was accompanied with high biomass yield and radical $\mathrm{pH}$ increase in all acids. High $\mathrm{H}_{2}$ generation had shown to improve acid consumption rate. The use of the three acids in a mixed substrate resulted to a drastic $\mathrm{pH}$ rise and lower $\mathrm{H}_{2}$ generation. This suggests that a more refined culture condition such as additional control of $\mathrm{pH}$ during fermentation must be kept to enhance the $\mathrm{H}_{2}$ productivity. Overall, the study provided a background on the $\mathrm{H}_{2}$ production using $R$. sphaeroides KCTC 1434 which might be a good
\end{abstract}

Keywords: Biohydrogen Production, Headspace Gas, $\mathrm{N}_{2}$-Fixation, Photofermentation, Rhodobacter sphaeroides production is through biological method (Das and Veziroglu, 2001). With a levelized cost of energy at USD $2-3 / \mathrm{kg}$ from 2008 to 2042, biohydrogen can compete with the cost of conventional fossil fuel in the global market (Lee, 2016).

Among the different ways of producing $\mathrm{H}_{2}$ from biomass, the use of Purple Non-Sulfur Bacteria (PNSB) such as Rhodobacter sphaeroides has been widely known due to their metabolic versatility, wide range of substrate utilization (Das and Veziroglu, 2001) and high product purity (Kars and Gunduz, 2010; Wu et al., 2012). The ability of these bacteria to photoheterotrophically convert organic acids into $\mathrm{H}_{2}$ and $\mathrm{CO}_{2}$ has made PNSB popular in wastewater remediation and alternative energy generation (Fang et al., 2005; 
Argun et al., 2008; Uyar et al., 2009; Amrouche et al., 2011; Han et al., 2012). Organic acids such as Volatile Fatty Acids (VFAs) produced during the acidogenic phase of anaerobic digestion of organic wastes can be further converted to $\mathrm{CO}_{2}$ and $\mathrm{H}_{2}$ (Kapdan and Kargi, 2006). The efficiency of light energy used for the production of $\mathrm{H}_{2}$ by photosynthetic bacteria is theoretically higher compared to cyanobacteria (Nath and Das, 2004).

Since the photoheterotrophic production of $\mathrm{H}_{2}$ requires anaerobic condition, purging of reactor headspace is done using an inert gas. Unlike other fermentation studies where a less costly $\mathrm{N}_{2}$ gas is employed, photo-fermentation commonly uses argon because $\mathrm{N}_{2}$ is the natural substrate for nitrogen fixation (Tao et al., 2008; Uyar et al., 2009; Kim et al., 2011; 2012a; Han et al., 2012; Pandey et al., 2012). When dimolecular nitrogen $\left(\mathrm{N}_{2}\right)$ is present, fixation dominates (Koku et al., 2002) and $\mathrm{H}_{2}$ production becomes minimal (Sasikala et al., 1990; Liu et al., 2009). Although $\mathrm{N}_{2}$ has been known to inhibit the $\mathrm{H}_{2}$ producing activity of preformed nitrogenase (Sweet and Burris, 1981; Liu et al., 2009) less has been written about the mechanism $\mathrm{H}_{2}$ generation under a nitrogen-fixing environment. When members of the Rhodospirillaceae family were grown on $\mathrm{N}_{2}$, R. sphaeroides and $R$. capsulatus showed the most rapid growth and highest in vivo nitrogenase activity among other species of the genus Rhodopseudomonas (Madigan et al., 1984). Hence, a further investigation in this line may lead to an opportunity of enhancing nitrogenase action for $\mathrm{H}_{2}$ production without the need of rigorous changes in the overall physiology and metabolism of the bacteria (Koku et al., 2002).

In this study, three VFAs (acetate, propionate and butyrate) that are identified to be the main fermentation products in dark fermentation liquor (Uyar et al., 2009) were chosen and $\mathrm{H}_{2}$ production under blue Light Emitting Diode (LED) and two different headspace gases, $\mathrm{N}_{2}$ and Ar, was investigated. The blue LED was selected because it was observed that $R$. sphaeroides KCTC 1434 illuminated with blue light exhibited the highest growth rate and cell concentration (Lee et al., 2011). Specifically, the objectives of the study were aimed at determining the effect of two different headspace gases, $\mathrm{N}_{2}$ and $\mathrm{Ar}$, on the $\mathrm{H}_{2}$ productivity of $R$. sphaeroides KCTC 1434 using individual and mixed acids such as acetate, propionate and butyrate.

\section{Materials and Methods}

\section{Microorganism and Growth Medium}

Rhodobacter sphaeroides KCTC 1434 was purchased from the Korean Collection for Type Culture (KCTC). The strain was initially grown on Van Niel's (VN) agar medium containing $\mathrm{K}_{2} \mathrm{HPO}_{4}\left(1 \mathrm{~g} \mathrm{~L}^{-1}\right), \mathrm{MgSO}_{4}(0.5 \mathrm{~g}$ $\left.\mathrm{L}^{-1}\right)$, yeast extract $\left(10 \mathrm{~g} \mathrm{~L}^{-1}\right)$ and $20 \mathrm{~g} \mathrm{~L}^{-1}$ agar. The strain was cultivated anaerobically on VN agar plates at $30 \pm 1^{\circ} \mathrm{C}$ under white LED lamp (4 k lux) (STK, Korea) inside an anaerobic chamber (COY Laboratory Products Inc., Grass Lake, MI) maintained using a gas mixture of $5 \% \mathrm{H}_{2}, 5 \% \mathrm{CO}_{2}$ and $90 \% \mathrm{~N}_{2}$. After ensuring the purity of the grown colonies, cells were scraped and transferred to serum bottles containing $60 \mathrm{~mL}$ of $\mathrm{VN}$ liquid medium (without agar) and incubated at $30 \pm 1{ }^{\circ} \mathrm{C}, 120 \pm 2 \mathrm{rpm}$, in blue LED lamp for $24 \mathrm{~h}$. Inoculums were then harvested by centrifugation at $4720 \times \mathrm{g}$ (Mega $17 \mathrm{R}$, Hanil Science Industrial Co., S. Korea) for $10 \mathrm{~min}$ at $4^{\circ} \mathrm{C}$. The pellets were washed with Modified Pfennig and Bieble (MPB) basal media prior to transfer in preactivation media. The MPB media used for preactivation and $\mathrm{H}_{2}$ production experiment had the following basal composition: $\mathrm{MgSO}_{4} \cdot 7 \mathrm{H}_{2} \mathrm{O}\left(0.2 \mathrm{~g} \mathrm{~L}^{-1}\right), \mathrm{NaCl}\left(0.4 \mathrm{~g} \mathrm{~L}^{-1}\right)$, yeast extract $\left(0.4 \mathrm{~g} \mathrm{~L}^{-1}\right), \mathrm{KH}_{2} \mathrm{PO}_{4}\left(0.5 \mathrm{~g} \mathrm{~L}^{-1}\right), \mathrm{CaCl}_{2} \cdot 2 \mathrm{H}_{2} \mathrm{O}(0.05 \mathrm{~g}$ $\left.\mathrm{L}^{-1}\right)$, ferric citrate $\left(5 \times 10^{-3} \mathrm{~g} \mathrm{~L}^{-1}\right), \mathrm{ZnCl}_{2}\left(0.07 \mathrm{mg} \mathrm{L}^{-1}\right)$, $\mathrm{H}_{3} \mathrm{BO}_{3}\left(0.06 \mathrm{mg} \mathrm{L} \mathrm{L}^{-1}\right), \mathrm{MnCl}_{2} \cdot 4 \mathrm{H}_{2} \mathrm{O} \quad\left(0.1 \mathrm{mg} \mathrm{L}^{-1}\right)$, $\mathrm{CoCl}_{2} \cdot 2 \mathrm{H}_{2} \mathrm{O}\left(0.2 \mathrm{mg} \mathrm{L}^{-1}\right), \mathrm{CuCl}_{2} \cdot 2 \mathrm{H}_{2} \mathrm{O}\left(0.02 \mathrm{mg} \mathrm{L}{ }^{-1}\right)$, $\mathrm{NiCl}_{2} \cdot 6 \mathrm{H}_{2} \mathrm{O}\left(0.02 \mathrm{mg} \mathrm{L}{ }^{-1}\right),\left(\mathrm{NH}_{4}\right)_{2} \mathrm{MoO}_{4} \cdot 2 \mathrm{H}_{2} \mathrm{O}(0.04 \mathrm{mg}$ $\left.\mathrm{L}^{-1}\right)$ and $\mathrm{HCl}(0.025 \% \mathrm{v} / \mathrm{v})$.

\section{Preactivation}

Preactivation in MPB minimal media was done following growth on $\mathrm{VN}$ liquid. In both growth and activation stage, $\mathrm{N}_{2}$ gas was used in purging the reactor headspace for $10 \mathrm{~min}$ to ascertain anaerobic condition. Preactivation of inoculums was also done at $30 \pm 1^{\circ} \mathrm{C}$, $120 \pm 2 \mathrm{rpm}$, in blue LED lamp for $24 \mathrm{~h}$. Preactivated cells were harvested by centrifugation as mentioned previously. The pellets were washed twice with MPB basal solution and resuspended in MPB $\mathrm{H}_{2}$ production media to serve as the inoculum for $\mathrm{H}_{2}$ production.

During preactivation stage, $7.5 \mathrm{mM}$ malic acid and $10 \mathrm{mM}$ sodium glutamate were used as carbon and nitrogen sources, respectively. For $\mathrm{H}_{2}$ production experiment, the malic acid is replaced with other carbon sources while sodium glutamate is reduced to 2 $\mathrm{mM}$ as optimized elsewhere (Eroglu et al., 1999). As growth factors, a vitamin solution was added with the following composition: Nicotinic acid $\left(0.2 \mathrm{mg} \mathrm{L}^{-1}\right)$, nicotinamide $\left(0.2 \mathrm{mg} \mathrm{L}^{-1}\right)$, thiamine $\mathrm{HCl}\left(0.4 \mathrm{mg} \mathrm{L}^{-1}\right)$ and biotin $\left(8.0 \mathrm{mg} \mathrm{L}^{-1}\right)$. The $\mathrm{pH}$ of the media for preactivation and $\mathrm{H}_{2}$ production set-up was adjusted to 6.8 using $5 \mathrm{M} \mathrm{NaOH}$. All reagents were purchased from Sigma-Aldrich Co (St. Louis, MO).

\section{$\mathrm{H}_{2}$ Production Experiment}

Three sets of $\mathrm{H}_{2}$-production batch experiments were conducted in duplicate using $160 \mathrm{~mL}$ serum bottles (Wheaton) containing $60 \mathrm{~mL}$ of inoculated medium. In the first set, $\mathrm{H}_{2}$ production from individual acids $(30 \mathrm{mM}$ acetate, $20 \mathrm{mM}$ propionate 
and $15 \mathrm{mM}$ butyrate) was determined under two different headspace gases $\left(\mathrm{Ar}\right.$ and $\mathrm{N}_{2}$ ). For the effect of headspace gases $\mathrm{N}_{2}$ and $\mathrm{Ar}$ on $\mathrm{H}_{2}$ production from mixed VFAs, a mixture of $15 \mathrm{mM}$ acetate, $10 \mathrm{mM}$ propionate and $7.5 \mathrm{mM}$ butyrate was used as substrate and purging was carried using $\mathrm{Ar}$ in one set of reactors and $\mathrm{N}_{2}$ in the other.

In all experiments, a $10 \mathrm{~min}$ purging of the reactor headspaces was done to ensure anaerobic condition, which was confirmed by Gas Chromatographic (GC) analysis. Sparging with either $\mathrm{Ar}$ or $\mathrm{N}_{2}$ was carried only at the initial preparation of the batch cultures and the pressure build up in each subsequent sampling was released through a tube connected to an acidified brine solution. Incubation was carried at $30 \pm 1{ }^{\circ} \mathrm{C}, 120 \pm 2 \mathrm{rpm}$, in blue LED lamp.

\section{Analytical Methods}

Gas samples were collected using a gas-tight glass syringe (Hamilton Co., Rem, Nevada) and biogas composition analysis was carried using GC (HP 6890 Series, Agilent Technologies, USA) equipped with ShinCarbon ST 100/120 micropacked (cat. \#19808) column and a thermal conductivity detector. The pressure $(\mathrm{P})$ in the bioreactors was measured using a pressure sensor (SIKA D-53695, Germany) and was converted into volume using the ideal gas law corrected to standard conditions (Pan et al., 2008; Kim et al., 2012b). Initial (P at time 0 and $P$ measurement following pressure release) and final (P measurement at the start of each sampling) volumes were multiplied with the $\%$ gas composition from GC analysis and the difference gave the volume of $\mathrm{H}_{2}$ gas generated. The $\mathrm{pH}$ of the culture media was measured using $\mathrm{pH}$ meter (Orion 290, CA, USA). Bacterial growth was monitored by measuring optical density at $660 \mathrm{~nm}$ using UV-Vis spectrophotometer (UV-1601PC, Shimadzu, Japan). Cell dry weight (DCW) was obtained using a standard curve where one unit of optical density corresponded to $0.27 \pm 0.06 \mathrm{~g} \mathrm{DCW} / \mathrm{L}$ medium. The concentration of the VFAs were analyzed after adding formic acid and 2ethylbutyrate using GC (HP 6890 Series, Agilent Technologies, USA) with a flame ionization detector and a capillary column (PB-FFAP, $0.25 \mu \mathrm{m}$, J\&W Scientific, Folsom, CA). All values were reported as standard deviation $( \pm)$ between each replicate.

\section{Kinetic Model Analysis and Other Indicators}

The cumulative $\mathrm{H}_{2}$ production in the batch experiments followed the modified Gompertz Equation (Han et al., 2012):

$$
H=P \exp \left\{-\exp \left[\frac{R_{m} e}{P}(\lambda-t)+1\right]\right\}
$$

where, $H$ is the cumulative $\mathrm{H}_{2}$ production $(\mathrm{mL}), P$ is the $\mathrm{H}_{2}$ production potential (mL), $R_{m}$ is the maximum $\mathrm{H}_{2}$ production rate $(\mathrm{mL} / \mathrm{h}), e$ is $2.71828, \lambda$ is the lag phase time (h) and $t$ is the incubation time (h). The values were determined by best fitting the $\mathrm{H}_{2}$ production experimental data for Equation 1 using the solver function in Microsoft Excel 2010 version (Newtonian algorithm). The kinetic parameters obtained where then used to describe the $\mathrm{H}_{2}$ production from each batch run.

The specific growth rate was calculated over the time interval where cell density increased linearly with time, using the following equation:

$\mu_{\max }=\frac{\ln \frac{x_{2}}{x_{1}}}{t_{2}-t_{1}}$

where, $\mu_{\max }$ is the specific growth rate and $x_{1}$ and $x_{2}$ are cell densities at two different time points in the exponential phase, $t_{1}$ and $t_{2}$. The biomass yield is the total amount of cell produced during the entire fermentation over the total substrate consumed. The $\mathrm{H}_{2}$ yield is computed as the cumulative $\mathrm{H}_{2}$ production per substrate consumed (in moles). The substrate consumption is the final amount of substrate consumed when the highest $\mathrm{H}_{2}$ production was achieved over the initial amount of substrate. The Maximum Substrate Consumption Rate (MSCR) is the amount of consumed substrate over the total time of fermentation when $\mathrm{H}_{2}$ production was at maximum. The Substrate Conversion Efficiency (SCE) is the actual moles of $\mathrm{H}_{2}$ produced over the amount of $\mathrm{H}_{2}$ calculated from the amount of substrate consumed (in moles). The specific $\mathrm{H}_{2}$ production rate (SHPR) is the cumulative $\mathrm{H}_{2}$ production per dry cell weight over the total time of fermentation.

\section{Results}

\section{$\mathrm{H}_{2}$ Production and Kinetic Profile from Individual Acids using $\mathrm{Ar}$ and $\mathrm{N}_{2}$ Headspace Gases}

$\mathrm{H}_{2}$ productivity of $R$. sphaeroides KCTC 1434 was investigated using $30 \mathrm{mM}$ acetate, $20 \mathrm{mM}$ propionate and $15 \mathrm{mM}$ butyrate. Similar to the method of Uyar et al. (2009), the VFA concentrations chosen were proportional to the number of carbon in each organic acid.

Propionate and butyrate exhibited a continuous $\mathrm{H}_{2}$ buildup under Ar headspace while a minimal amount of $\mathrm{H}_{2}$ was produced from acetate as illustrated in Fig 1a. Within a $276 \mathrm{~h}$ experimental duration, the amount of $\mathrm{H}_{2}$ accumulated from acetate, propionate and butyrate in argon-purged reactorswere 2.20, 157.95 and $160.58 \mathrm{~mL}$ (Fig. 1a and Table 1), respectively. In the reactors with $\mathrm{N}_{2}$-purged headspace, the $\mathrm{H}_{2}$ generation time lasted for 
$165 \mathrm{~h}$ with a cumulative production of $1.66 \mathrm{~mL}$ in acetate, $6.41 \mathrm{~mL}$ in propionate and $6.93 \mathrm{~mL}$ in butyrate (Fig. 1b, Table 1). While acetate evolved a minimal amount of $\mathrm{H}_{2}$ regardless of the headspace gas used, the Ar-sparged propionate and butyrate reactors gave $\mathrm{H}_{2}$ volumes that were 24.64 and 23.17 times higher than their $\mathrm{N}_{2}$ - sparged counterparts.
The $\mathrm{N}_{2}$-purged reactors exhibited a growth associated $\mathrm{H}_{2}$ evolution. The volume of $\mathrm{H}_{2}$ produced rose at the exponential phase of cell growth and leveled off at the onset of stationary phase. This trend was not seen in Arpurged reactors wherein a sustained increase of $\mathrm{H}_{2}$ volume was obtained along the stationary phase of cell growth.

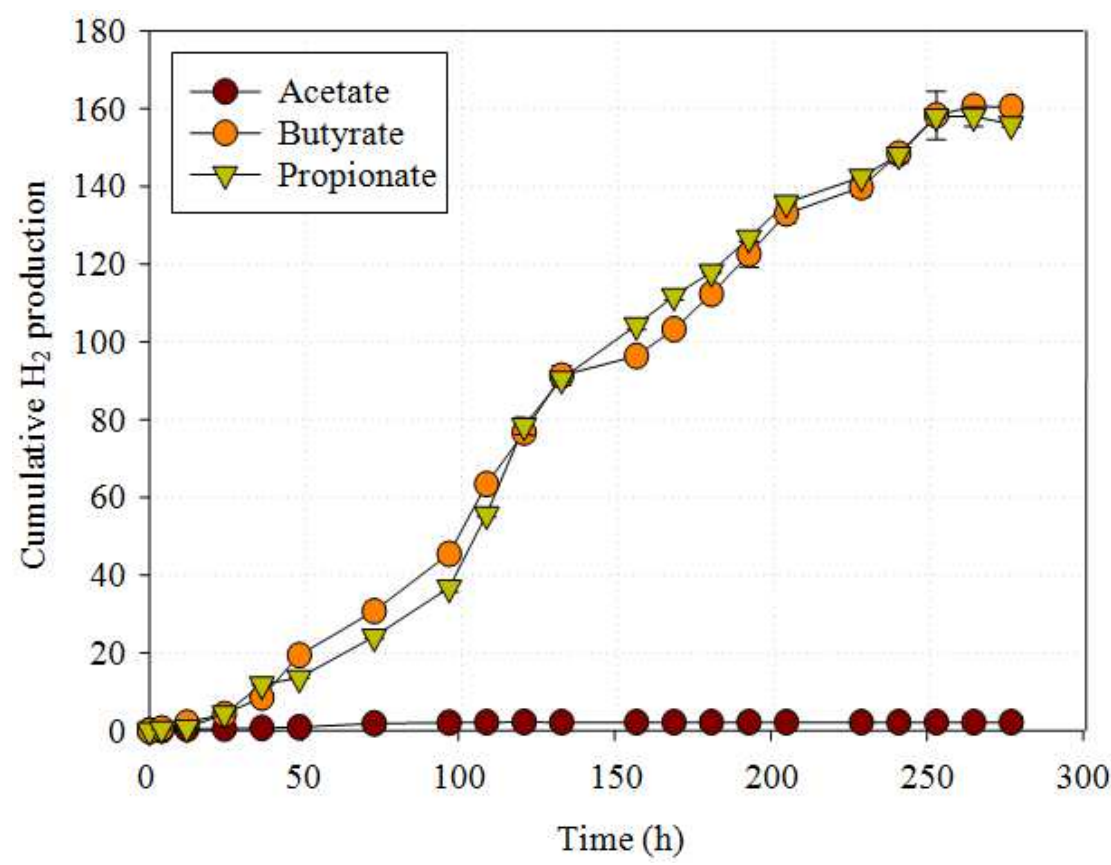

(a)

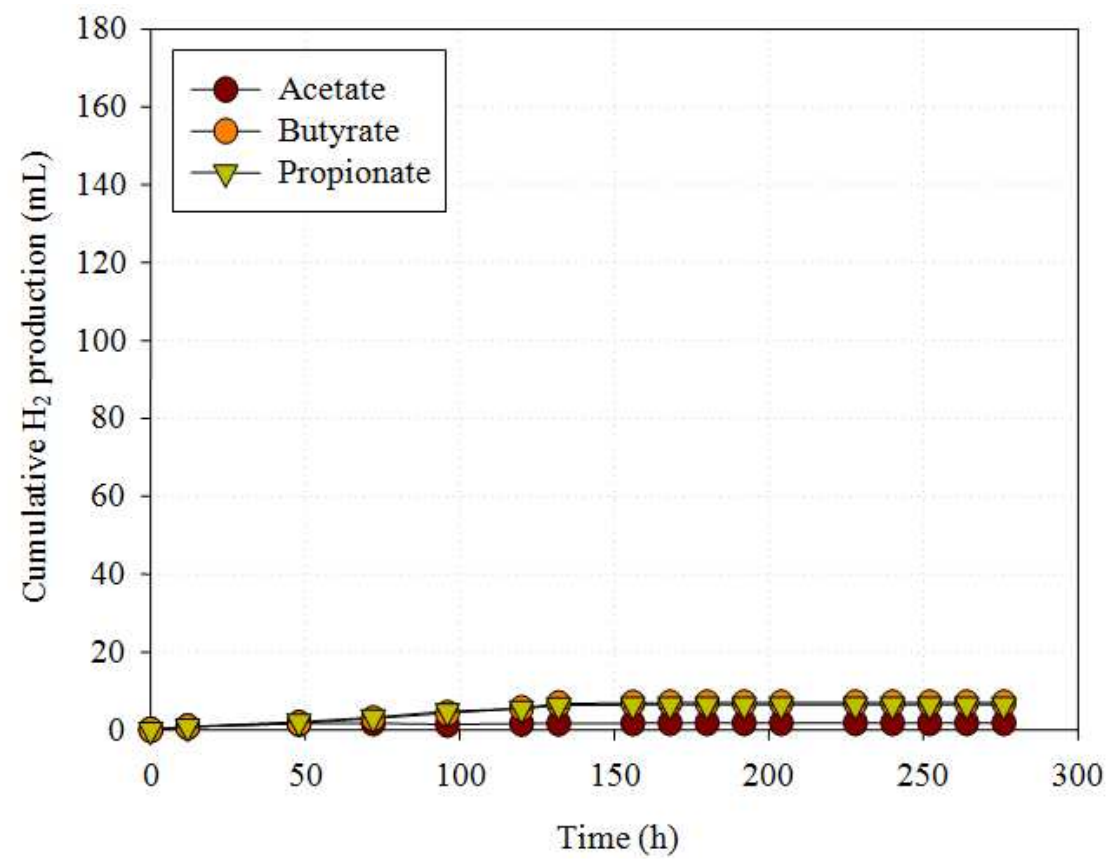

(b)

Fig. 1. Cumulative $\mathrm{H}_{2}$ production from acetate, propionate and butyrate under (a) Ar and (b) $\mathrm{N}_{2}$ headspace 
Table 1. Kinetic parameters from modified Gompertz analysis of $\mathrm{H}_{2}$ production from acetate, propionate, butyrate under $\mathrm{Ar}$ and $\mathrm{N}_{2}$ headspace

\begin{tabular}{|c|c|c|c|c|c|c|}
\hline \multirow{2}{*}{$\begin{array}{l}\text { Gompertz } \\
\text { Parameters }\end{array}$} & \multicolumn{2}{|c|}{ Acetate } & \multicolumn{2}{|c|}{ Propionate } & \multicolumn{2}{|l|}{ Butyrate } \\
\hline & $\mathrm{Ar}$ & $\mathrm{N}_{2}$ & $\mathrm{Ar}$ & $\mathrm{N}_{2}$ & $\mathrm{Ar}$ & $\mathrm{N}_{2}$ \\
\hline$P\left(\mathrm{~mL} \mathrm{H}_{2}\right)$ & 2.200 & 1.660 & 157.950 & 6.410 & 160.580 & 6.930 \\
\hline$R_{\mathrm{m}}(\mathrm{mL} / \mathrm{h})$ & 0.020 & 0.050 & 1.200 & 0.070 & 0.900 & 0.060 \\
\hline$\lambda(\mathrm{h})$ & 7.000 & 0.000 & 63.000 & 0.000 & 40.000 & 0.000 \\
\hline$R^{2}$ & 0.989 & 0.974 & 0.997 & 0.995 & 0.996 & 0.995 \\
\hline
\end{tabular}

Table 2. $\mathrm{H}_{2}$ productivity and substrate consumption of $R$. sphaeroides KCTC 1434 from individual VFAs in Arand $\mathrm{N}_{2}$ headspace

\begin{tabular}{llllllll}
\hline $\begin{array}{l}\text { Carbon } \\
\text { sources }\end{array}$ & $\begin{array}{l}\mathrm{Head} \text { gas } \\
\text { gace }\end{array}$ & $\begin{array}{l}\text { Amount of } \\
\mathrm{H}_{2} \text { Produced } \\
(\mathrm{mL})\end{array}$ & $\mathrm{SC}(\%)$ & $\begin{array}{l}\text { MSCR } \\
(\mathrm{mM} / \mathrm{h})\end{array}$ & $\begin{array}{l}\mathrm{H}_{2} \text { Yield }(\mathrm{mol} \\
\mathrm{H}_{2} / \text { mol substrate } \\
\text { consumed })\end{array}$ & $\begin{array}{l}\mathrm{S} \text { \%SCE } \\
\left(\mathrm{mL} \mathrm{H}_{2} / \mathrm{g}\right. \\
\mathrm{DCW} \cdot \mathrm{h})\end{array}$ \\
\hline Acetate & $\mathrm{Ar}$ & $2.20 \pm 0.087$ & $75.40 \pm 3.5$ & $0.34 \pm 0.05$ & $0.07 \pm 0.01$ & $1.79 \pm 0.05$ & $0.32 \pm 0.07$ \\
Acetate & $\mathrm{N}_{2}$ & $1.66 \pm 0.15$ & $22.53 \pm 1.2$ & $0.16 \pm 0.04$ & $0.06 \pm 0.02$ & $1.50 \pm 0.03$ & $0.15 \pm 0.01$ \\
Propionate & $\mathrm{Ar}$ & $157.95 \pm 0.41$ & $96.11 \pm 0.9$ & $0.10 \pm 0.01$ & $6.10 \pm 0.15$ & $87.16 \pm 1.40$ & $12.54 \pm 0.44$ \\
Propionate & $\mathrm{N}_{2}$ & $6.41 \pm 0.24$ & $41.45 \pm 0.7$ & $0.06 \pm 0.02$ & $0.49 \pm 0.06$ & $7.01 \pm 0.95$ & $0.94 \pm 0.03$ \\
Butyrate & $\mathrm{Ar}$ & $160.58 \pm 1.24$ & $91.71 \pm 1.3$ & $0.05 \pm 0.05$ & $8.84 \pm 0.08$ & $88.42 \pm 1.52$ & $11.68 \pm 0.88$ \\
Butyrate & $\mathrm{N}_{2}$ & $6.93 \pm 0.13$ & $29.29 \pm 1.1$ & $0.03 \pm 0.03$ & $1.22 \pm 0.07$ & $12.16 \pm 0.86$ & $1.04 \pm 0.09$ \\
\hline
\end{tabular}

Table 3. Growth kinetic parameters of R. sphaeroides KCTC 1434 from individual VFAs in Ar-and $\mathrm{N}_{2}$-purged reactors

\begin{tabular}{llllll}
\hline $\begin{array}{l}\text { Carbon } \\
\text { sources }\end{array}$ & $\begin{array}{l}\text { Headspace } \\
\text { gas }\end{array}$ & $\begin{array}{l}\text { Biomass yield } \\
(\mathrm{g} \text { DCW/g substrate })\end{array}$ & $\begin{array}{l}\text { Final DCW }(\mathrm{g} \\
\mathrm{DCW} / \mathrm{L} \text { medium })\end{array}$ & $\mu_{\max }\left(\mathrm{h}^{-1}\right)$ & Final $\mathrm{pH}$ \\
\hline Acetate & $\mathrm{Ar}$ & $0.39 \pm 0.02$ & $1.11 \pm 0.05$ & $0.014 \pm 0.003$ & $10.3 \pm 0.1$ \\
Acetate & $\mathrm{N}_{2}$ & $0.32 \pm 0.03$ & $1.00 \pm 0.04$ & $0.028 \pm 0.005$ & $10.3 \pm 0.2$ \\
Propionate & $\mathrm{Ar}$ & $0.25 \pm 0.05$ & $0.83 \pm 0.04$ & $0.009 \pm 0.002$ & $7.5 \pm 0.1$ \\
Propionate & $\mathrm{N}_{2}$ & $0.33 \pm 0.07$ & $0.87 \pm 0.03$ & $0.003 \pm 0.004$ & $8.9 \pm 0.0$ \\
Butyrate & $\mathrm{Ar}$ & $0.33 \pm 0.03$ & $0.87 \pm 0.06$ & $0.005 \pm 0.002$ & $7.2 \pm 0.1$ \\
Butyrate & $\mathrm{N}_{2}$ & $0.47 \pm 0.06$ & $0.95 \pm 0.01$ & $0.003 \pm 0.001$ & $9.1 \pm 0.2$ \\
\hline
\end{tabular}

Modified Gompertz fitting was done using the $\mathrm{H}_{2}$ production data to determine parameters that can aid in interpreting the results (Table 1). The lowest $\mathrm{H}_{2}$ production rates $\left(R_{\mathrm{m}}\right)$ were derived from acetate $(0.02 \mathrm{~mL}$ $\mathrm{h}^{-1}$ in Ar- purged and $0.05 \mathrm{~mL} \mathrm{~h}^{-1}$ in $\mathrm{N}_{2}$-purged reactors), while the highest rate was obtained from propionate $(1.20$ $\left.\mathrm{mL} \mathrm{h}^{-1}\right)$ followed by butyrate $\left(0.90 \mathrm{~mL} \mathrm{~h}^{-1}\right)$ in Ar-purged reactors. Propionate $\left(0.07 \mathrm{~mL} \mathrm{~h}^{-1}\right)$ and butyrate $(0.06 \mathrm{~mL}$ $\mathrm{h}^{-1}$ ) had lower $\mathrm{H}_{2}$ production rates under $\mathrm{N}_{2}$ headspace. The Gompertz-derived $\lambda$ values showed no $\mathrm{H}_{2}$ production lag times in $\mathrm{N}_{2}$-purged reactors while 7, 63 and $40 \mathrm{~h}$ were determined as $\mathrm{H}_{2}$ production lag times for acetate, propionate and butyrate containing Ar-purged reactors, respectively. The Gompertz-fitted data had correlation coefficient values ranging from 0.974 to 0.997 .

The consumption rate of each substrate (SCR) was not substantially affected by the difference in headspace gas. As reflected from the VFA analyses (Table 2), there was only a slight variation in the acetate consumption rate under $\operatorname{Ar}(\mathrm{SCR}=0.17)$ and $\mathrm{N}_{2}(\mathrm{SCR}=0.15)$. The same was true with propionate (SCR under $\mathrm{Ar}=0.07$, SCR under $\mathrm{N}_{2}=0.06$ ) and butyrate (SCR under $\mathrm{Ar}=$ 0.05 , SCR under $\mathrm{N}_{2}=0.03$ ). Despite the low $\mathrm{H}_{2}$ evolution, the highest $\mathrm{SCR}$ and cell growth were observed from acetate with specific growth rates $\left(\mu_{\max }\right)$ of 0.028 and 0.014 for $\mathrm{N}_{2}$ - and Ar-purged reactors, respectively (Table 3). Furthermore, the final $\mathrm{pH}$ was also greater in $\mathrm{N}_{2}$ - than in Ar-purged reactors, with the exemption of acetate $\left(\mathrm{pH}=10.3\right.$, under $\mathrm{N}_{2}$ and $\mathrm{Ar}$ headspace). From an initial value of 6.8 , the $\mathrm{pH}$ rose to 8.9 and 8.1 in propionate and butyrate containing $\mathrm{N}_{2}$ purged reactors, respectively (Table 3 ). These final $\mathrm{pH}$ values were higher compared to those of Ar-purged reactors whose values were $\mathrm{pH} 7.5$ (propionate) and $\mathrm{pH}$ 7.2 (butyrate) (Table 3).

$\mathrm{H}_{2}$ yield, Substrate Conversion Efficiency (SCE) and Specific $\mathrm{H}_{2}$ Production Rate (SHPR) are useful parameters in characterizing microbial $\mathrm{H}_{2}$ production. $\mathrm{H}_{2}$ yield is the amount of $\mathrm{H}_{2}$ produced per amount of substrate consumed. As shown in Table 2, almost similar $\mathrm{H}_{2}$ yields ( $0.07 \mathrm{~mol} \mathrm{H}_{2} / \mathrm{mol}$ substrate in Ar- and $0.06 \mathrm{~mol} \mathrm{H}_{2} / \mathrm{mol}$ substrate in $\mathrm{N}_{2}$ ) were obtained from acetate under the two headspace gases, while yields from propionate and butyrate were higher in Ar- (6.10 and $8.84 \mathrm{~mol} \mathrm{H}_{2} / \mathrm{mol}$ substrate, respectively) than in $\mathrm{N}_{2^{-}}(0.49$ and $1.22 \mathrm{~mol}$ $\mathrm{H}_{2} /$ mol substrate, respectively) sparged reactors.

The theoretical production of $\mathrm{H}_{2}$ from acetate, propionate and butyrate is described by the following equation: 


$$
\begin{aligned}
& \text { Acetate: } \mathrm{C}_{2} \mathrm{H}_{4} \mathrm{O}_{2}+2 \mathrm{H}_{2} \mathrm{O} \rightarrow 4 \mathrm{H}_{2}+2 \mathrm{CO}_{2} \\
& \text { Propionate } \mathrm{C}_{3} \mathrm{H}_{6} \mathrm{O}_{2}+4 \mathrm{H}_{2} \mathrm{O} \rightarrow 7 \mathrm{H}_{2}+3 \mathrm{CO}_{2} \\
& \text { Butyrate: } \mathrm{C}_{4} \mathrm{H}_{8} \mathrm{O}_{2}+6 \mathrm{H}_{2} \mathrm{O} \rightarrow 10 \mathrm{H}_{2}+4 \mathrm{CO}_{2}
\end{aligned}
$$

SCE is equal to the ratio of moles of $\mathrm{H}_{2}$ actually obtained divided by the moles of $\mathrm{H}_{2}$ expected through stoichiometric conversion of the substrate consumed according to the chemical reactions (3), (4) and (5). This parameter reflects how much of the substrate has been utilized for $\mathrm{H}_{2}$ production other than growth or alternative biosynthesis (Yiilmaz et al., 2010; Kim et al., 2011). From the experiment, there was no remarkable difference between the SCE of acetate in Ar- (1.79\%) and $\mathrm{N}_{2}$ - purged reactors $(1.50 \%)$, while argon-purged propionate and butyrate reactors have SCEs that were 12.4 and 7.3 times larger than their $\mathrm{N}_{2}$-purged counterparts. Under Ar headspace, the SCE of butyrate and propionate were 88.42 and 87.16 , respectively. SHPR values from acetate, propionate and butyrate were likewise 3.6, 12.4 and 11.2 times greater in Ar- than in $\mathrm{N}_{2}$-sparged reactors.

The $\mathrm{H}_{2}$ Production of $\mathrm{R}$. Sphaeroides KCTC 1434 from Mixed VFAs using Ar and $\mathrm{N}_{2}$ Headspace Gas

Using the conditions previously stated in the methodology section, $\mathrm{H}_{2}$ production in mixed VFAs $(15$ $\mathrm{mM}$ acetate, $10 \mathrm{mM}$ propionate and $7.5 \mathrm{mM}$ butyrate) was investigated under $\mathrm{Ar}$ and $\mathrm{N}_{2}$ headspace gases. As depicted in Fig. 2a, a low $\mathrm{H}_{2}$ production was obtained with $\mathrm{N}_{2}$ sparging while no remarkable difference was observed in the cell density under $\mathrm{Ar}$ and $\mathrm{N}_{2}$ headspaces. The volumes of $\mathrm{H}_{2}$ evolved were $31.44 \mathrm{~mL}$ in $\mathrm{N}_{2}$ and $47.12 \mathrm{~mL}$ in Ar-sparged reactors. $\mathrm{H}_{2}$ was produced until $168 \mathrm{~h}$ in Ar headspace, a duration that was twice longer than in $\mathrm{N}_{2}$, where a leveling off of $\mathrm{H}_{2}$ evolution was observed after $72 \mathrm{~h}$.

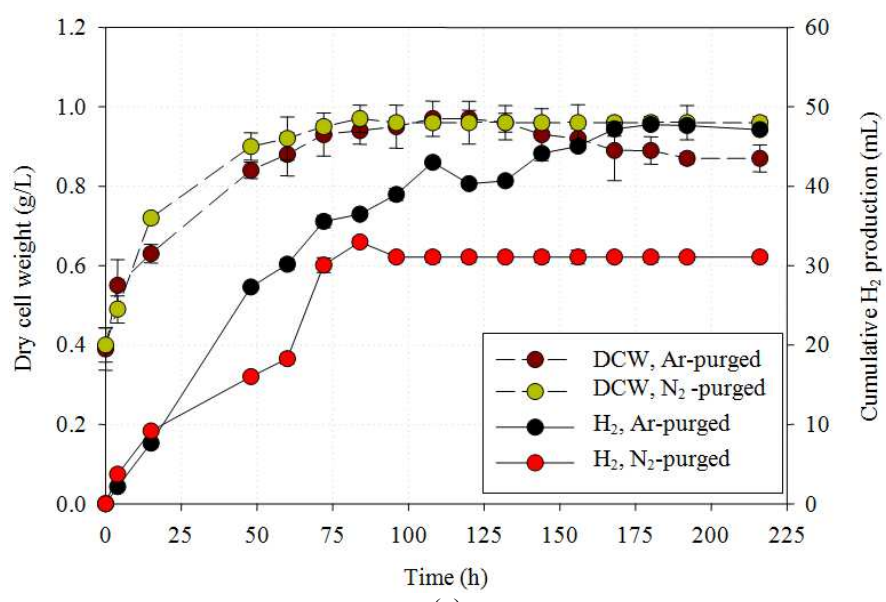

(a)

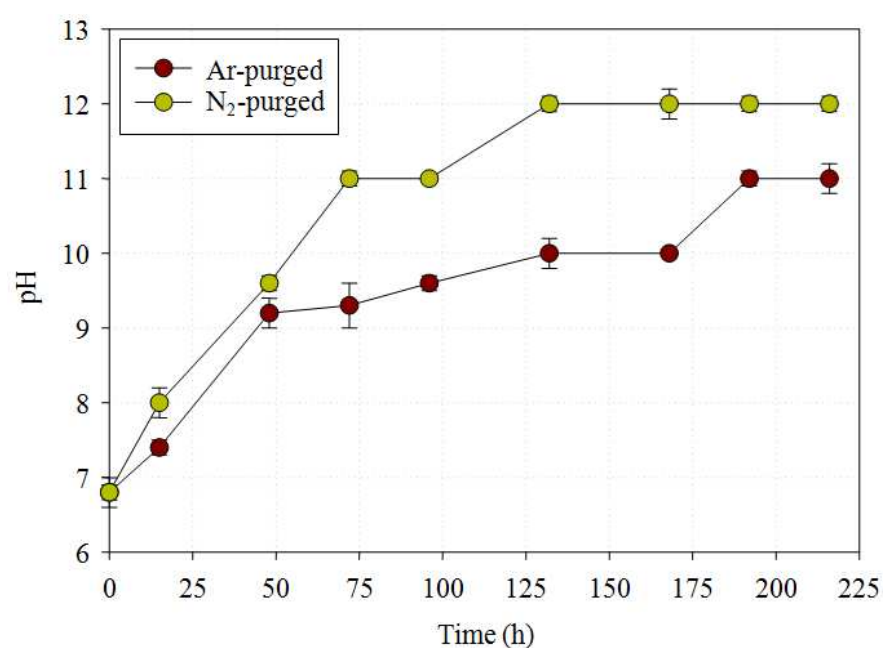

(b)

Fig. 2. (a) Cumulative $\mathrm{H}_{2}$ production and cell density and (b) $\mathrm{pH}$ change during $\mathrm{H}_{2}$ production of $R$. sphaeroides $\mathrm{KCTC} 1434$ from mixed VFAs under $\mathrm{Ar}$ and $\mathrm{N}_{2}$ headspace 
Table 4. Kinetic parameters and substrate conversion during $\mathrm{H}_{2}$ production of R. sphaeroides $\mathrm{KCTC} 1434$ in $\mathrm{Ar}$-and $\mathrm{N}_{2}$-purged reactors using mixed VFAs

\begin{tabular}{|c|c|c|c|c|c|c|c|c|}
\hline \multirow{3}{*}{$\begin{array}{l}\text { Headspace } \\
\text { Gas }\end{array}$} & \multicolumn{8}{|c|}{ Kinetic parameters } \\
\hline & \multirow{2}{*}{$\begin{array}{l}P(\mathrm{~mL} \\
\left.\mathrm{H}_{2} \text { produced }\right)\end{array}$} & \multirow{2}{*}{$\begin{array}{l}R_{\mathrm{m}} \\
\text { (slope) }\end{array}$} & \multirow[b]{2}{*}{$\lambda(\mathrm{h})$} & \multirow[b]{2}{*}{$R^{2}$} & \multicolumn{3}{|c|}{ Substrate consumption rates $(\mathrm{mM} / \mathrm{h})$} & \multirow[b]{2}{*}{ SCE $(\%)$} \\
\hline & & & & & Acetate & Propionate & Butyrate & \\
\hline $\mathrm{Ar}$ & 47.20 & 0.58 & 7 & 0.991 & 0.04 & 0.02 & 0.01 & 52.14 \\
\hline $\mathrm{N}_{2}$ & 32.97 & 0.61 & 0 & 0.969 & 0.12 & 0.06 & 0.03 & 19.45 \\
\hline
\end{tabular}

The $\mathrm{pH}$ quickly increased to 9.6 in Ar-purged reactors during the first $48 \mathrm{~h}$, rising to a final value of 11 in $216 \mathrm{~h}$ (Fig. 2b). The rise of $\mathrm{pH}$ was more drastic in $\mathrm{N}_{2}$ reactors where a linear increase to a value of 11 was obtained in $72 \mathrm{~h}$ and a final $\mathrm{pH}$ value of 12 in $130 \mathrm{~h}$.

Using modified Gompertz analysis, $\lambda$ was determined to be 7 and $0 \mathrm{~h}$ in Ar- and $\mathrm{N}_{2}$-purged reactors respectively (Table 4). This observation conferred with the previous experiments in which the lag time values were lower in $\mathrm{N}_{2}$ than in $\mathrm{Ar}$ headspace. Gompertzpredicted $R_{\mathrm{m}}$ values were $0.61 \mathrm{~mL} \mathrm{H}_{2} / \mathrm{h}$ in Ar-purged reactors and $0.58 \mathrm{~mL} \mathrm{H}_{2} / \mathrm{h}$ in $\mathrm{N}_{2}$-purged reactors.

Under Ar headspace, consumption rates were 0.04, 0.02 and $0.01 \mathrm{mM} \mathrm{h}^{-1}$ in acetate, propionate and butyrate, respectively (Table 4). Relatively higher consumption rates were observed under $\mathrm{N}_{2}$ headspace at $0.12 \mathrm{mM} \mathrm{h}^{-1}$ for acetate, $0.06 \mathrm{mM} \mathrm{h}^{-1}$ for propionate and $0.03 \mathrm{mM} \mathrm{h}^{-1}$ for butyrate. Hence, among the three acids, acetate was consumed the fastest regardless of the headspace gas. The SCEs were observed to be $30.70 \%$ under Ar headspace and $19.45 \%$ under $\mathrm{N}_{2}$ headspace.

\section{Discussion}

The $\mathrm{H}_{2}$ Production of $\mathrm{R}$. sphaeroides KCTC 1434 from Individual Acids

Acetic, propionic and butyric acid generally accounts for $70-80 \%$ of the VFAs in acidogenic reactors of anaerobic digestion (Fang and $\mathrm{Yu}, 2002$; Shi and $\mathrm{Yu}$, 2006). Hence, these substrates were chosen for this investigation. As shown in the results, $R$. sphaeroides KCTC 1434 grew well in the three acids however high $\mathrm{H}_{2}$ production was observed only in propionate $(87.16 \%$ SCE) and butyrate (88.42\% SCE) under Ar headspace. Although a wide range of studies on carbon utilization for $\mathrm{H}_{2}$ production in PNSB is available, discrepancies exist even for different strains of $R$. sphaeroides. For instance, most studies reported highest $\mathrm{H}_{2}$ production in acetate, followed by propionate, then butyrate (Uyar et al., 2009; Lo et al., 2011; Han et al., 2012). Using individual acid substrate, Uyar et al. (2009) obtained SCEs of 33, 31 and $14 \%$ in acetate, propionate and butyrate, respectively. Han et al. (2012) also had similar findings in $R$. sphaeroides $\mathrm{RV}$ when they investigated the effect of different carbon sources in $\mathrm{H}_{2}$ productivity. In their report, the use of different concentrations of acids gave corresponding SCE values between $97.4-99.9 \%$ in acetate, $70.7-86.4 \%$ in propionate and $56.2-81.6 \%$ in butyrate. Other studies however reported dissimilar trends (Tao et al., 2008; Lo et al., 2011). In the investigation of Tao et al. (2008), isolated strains identified as $R$. sphaeroides ZX-2, ZX-3, ZX-4 and ZX5 exhibited variable preference for acetate and butyrate. Strain ZX-2 was able to utilize butyrate at $6.45 \% \mathrm{SCE}$ while acetate was not used for both growth and $\mathrm{H}_{2}$ production; ZX-3 gave 63.20 and $4.61 \%$ SCE in acetate and butyrate, respectively; ZX-4 was not able to utilize both acids; while ZX-5 gave the highest SCE at 69.00 and $71.50 \%$ for acetate and butyrate, respectively. The variations in reported data from literatures confirm the complexity and flexibility of PNSB metabolism and therefore require investigation of each type of strain (Koku et al., 2002; Kim et al., 2012a).

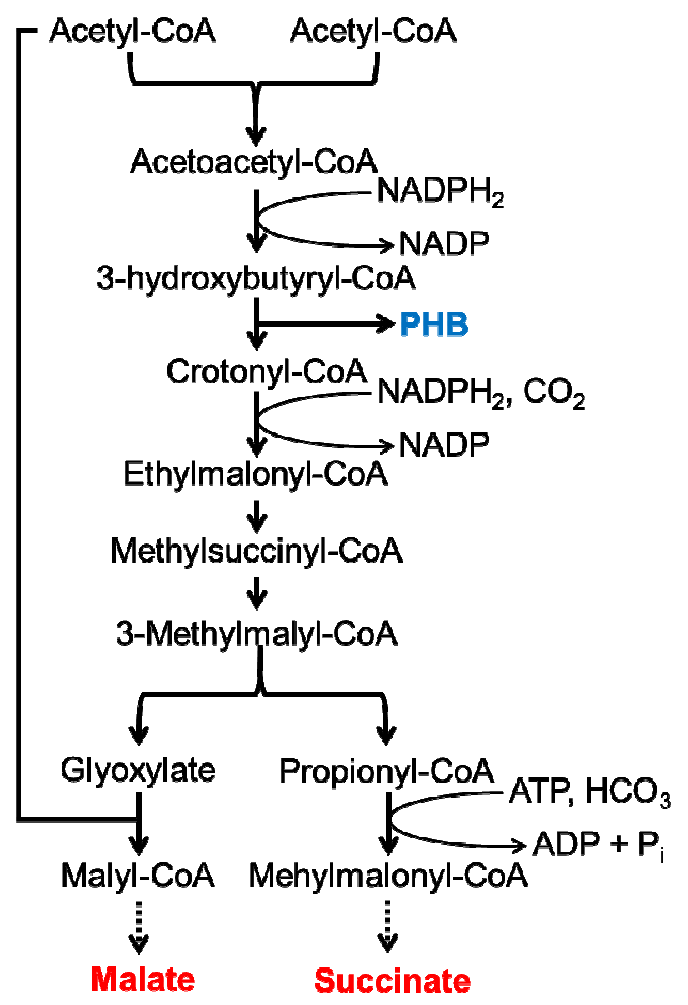

Fig. 3. Ethylmalonyl-CoA pathway operating in R. sphaeroides sp. (lifted from Kars and Gunduz, 2010) 
In our study, the use of acetate was associated with low $\mathrm{H}_{2}$ production (Fig. 1), high cell density increase and high final $\mathrm{pH}$ (Table 3). There was no substantial difference between the SCE of acetate in $\mathrm{Ar}$ and $\mathrm{N}_{2}$ purged reactors (1.79 and 1.50 , respectively). This may be indicative of a metabolic route that competes with nitrogen-fixation and is inherent only to acetate assimilation. Due to the missing isocitrate lyase of $R$. sphaeroides, the uptake of acetate may occur through the ethylmalonyl-CoA pathway (Fig. 3) with the following net stoichiometry (Erb et al., 2007; Balat et al., 2009):

$$
\begin{aligned}
& 3 \text { Acetyl }-\mathrm{CoA}+2 \mathrm{CO}_{2}+2 \mathrm{NADPH}+2 \mathrm{NAD} \\
& +<\text { pmf }>\rightarrow 2 \text { malate }+2 \mathrm{NADH}+2 \mathrm{NADP}+3 \mathrm{CoA}
\end{aligned}
$$

In the aspect of biohydrogen production, this pathway holds two disadvantages. First, it requires Adenosine Triphosphate (ATP) and reducing power in the form of $\mathrm{NADPH}_{2}$ which diminishes energy and electron output; and second, it shares common elements with Polyhydroxybutyrate (PHB) biosynthetic route (Kars and Gunduz, 2010). The production of polyhydroxyalkanoates (e.g., PHB) as an intracellular storage material is another route that competes with the $\mathrm{H}_{2}$ production in disposing excess reducing equivalents in cells (Hustede et al., 1993). PHB production is often seen as one of the critical factors associated with low $\mathrm{H}_{2}$ productivity during utilization of organic substrate in photo fermentation (Khatipov et al., 1998; Kobayashi et al., 2011; Koku et al., 2002; Han et al., 2012; Pandey et al., 2012). In the study of Pandey et al. (2012) using $R$. sphaeroides NMBL-01, lactate and PHB were end metabolites formed during photo fermentation of acetate and butyrate. Han et al. (2012) also found that increasing concentrations of acetate and butyrate gave lower $\mathrm{H}_{2}$ production and higher PHB accumulation, while no PHB was detected during $\mathrm{H}_{2}$ production from different concentrations of propionate. While they reported SCEs of $98.0 \%$ at $2.4 \mathrm{~g}^{-1} \mathrm{~L}$ acetate, $78.3 \%$ at $2.0 \mathrm{~g} \mathrm{~L}^{-1}$ propionate and $81.6 \%$ at $1.8 \mathrm{~g} \mathrm{~L}^{-1}$ butyrate, our study (using $2.5 \mathrm{~g} \mathrm{~L}^{-1}$ sodium acetate, $1.92 \mathrm{~g} \mathrm{~L}^{-1}$ sodium propionate, $1.65 \mathrm{~g} \mathrm{~L}^{-1}$ sodium butyrate) gave higher SCEs except for acetate. It is not however clear whether $R$. sphaeroides KCTC 1434 have the same assimilation pathway for acetate and butyrate, or whether it has assimilation pathway distinct from the strains reported in these literatures. Nevertheless, taking into account the ethylmalonyl pathway of acetate assimilation in $R$. sphaeroides and the fact that acetate is the most advantageous substrate for PHB production, our findings stand theoretically sound. Furthermore, $\mathrm{H}_{2}$ production using acetate and PHB-producing systems in photoheterotrophic $\mathrm{H}_{2}$ generation have been reported to exhibit elevated $\mathrm{pH}$ (Hustede et al., 1993; Khatipov et al., 1998; Uyar et al., 2009; Kim et al., 2011; 2012a). Hustede et al. (1993) showed that $R$. sphaeroides ATCC 17023 grown in un buffered mineral medium containing $10 \mathrm{mM}$ acetate had complete consumption of the acid and had a $\mathrm{pH}$ increase of 10.0 within 1 day, while Khatipov et al. (1998) reported that $R$. sphaeroides $\mathrm{RV}$ grown in glutamate as $\mathrm{N}$ source had significantly higher $\mathrm{pH}$ and $\mathrm{PHB}$ content but very low $\mathrm{H}_{2}$ production in acetate than in lactate and pyruvate. As the amount of PHB increases with increased $\mathrm{pH}$, the use of acetate as substrate therefore facilitates PHB accumulation (Khatipov et al., 1998; Kim et al., 2012a). Although the determination of PHB was not within the scope of our study, the low $\mathrm{pH}$ and high biomass yield among acetate-fed reactors may signify the occurrence of an $\mathrm{H}_{2}$-competing pathway such as the ethylmalonyl-CoA during acetate assimilation (Fig. 3).

It can be observed from Table 2 that high $\mathrm{H}_{2}$ generation was associated with high substrate consumption (\%SC) but low MSCR. MSCR is the amount of substrate consumed over the total fermentation time when $\mathrm{H}_{2}$ production was at maximum. Propionate and butyrate had 96.11 and $91.71 \%$ SC under Ar headspace but with an MSCR of 0.10 and $0.05 \mathrm{mM} \mathrm{h}^{-1}$, respectively. This indicates that majority of the propionate and butyrate consumed were converted to $\mathrm{H}_{2}$ and only a minute portion were used for growth or alternative biosynthesis. SHPR is the biomass weight-normalized $\mathrm{H}_{2}$ production rate. Acetate under Ar headspace had a $75.40 \% \mathrm{SC}, 0.34 \mathrm{mM} / \mathrm{h}$ MSCR and an SHPR of $0.32 \mathrm{~mL} \mathrm{H} / \mathrm{g} \mathrm{DCW} \cdot \mathrm{h}$, which denote that $R$. sphaeroides preferred acetate for biosynthesis instead of $\mathrm{H}_{2}$ production.

It is worth mentioning that $\mathrm{H}_{2}$ generation improves organic acid utilization (Table 2). Ar sparged reactors exhibited $96.11 \%$ propionate consumption and $91.71 \%$ butyrate consumption with SHPRs of 12.54 and 11.68 $\mathrm{mL} \mathrm{H}_{2} / \mathrm{g} \mathrm{DCW} \cdot \mathrm{h}$, respectively. Higher acetate consumption was observed under $\operatorname{Ar}(75.40 \%)$ than $\mathrm{N}_{2}$ headspace $(22.53 \%)$ with SHPR values of 0.32 and 0.15 $\mathrm{mL} \mathrm{H}_{2} / \mathrm{g} \mathrm{DCW} \cdot \mathrm{h}$, respectively. Since the use of sequential dark fermentation and photo fermentation in a combined two-stage process has been seen as an attractive technology for the enhancement of $\mathrm{H}_{2}$ production from waste material substrates ( $\mathrm{Su}$ et al., 2009; Laurinavichene et al., 2010; Chookaew et al., 2015), the strain may be further evaluated for its potential use in co-culture dual-stage fermentation system.

\section{The Effect of Headspace Gas on $\mathrm{H}_{2}$ Production}

The presence of $\mathrm{N}_{2}$ gas in reactor headspaces provided a nitrogen-fixing environment to the $R$. sphaeroides strain. An obvious inhibition was exhibited by all $\mathrm{N}_{2}$-sparged reactors. SHPRs of 0.32 (acetate), 12.54 (propionate) and 11.68 (butyrate) $\mathrm{mL} \mathrm{H}_{2} / \mathrm{g} \mathrm{DCW} \cdot \mathrm{h}$ under Ar sparging were reduced to 0.15 (acetate), 0.94 (propionate) and $1.04 \mathrm{~mL}$ (butyrate) $\mathrm{H}_{2} / \mathrm{g} \mathrm{DCW} \cdot \mathrm{h}$ in the presence of $\mathrm{N}_{2}$. The lower $\mathrm{H}_{2}$ evolution in $\mathrm{N}_{2}$-sparged 
reactors was accompanied with high biomass yield and high final $\mathrm{pH}$ (Table 3 ).

While lower production rates $\left(R_{\mathrm{m}}\right)$ were derived (Table 1 ), all $\mathrm{N}_{2}$ - sparged reactors had $0 \mathrm{~h}$ production lag times $(\lambda)$. This indicates a growth-associated $\mathrm{H}_{2}$ production in the presence of $\mathrm{N}_{2}$. Under $\mathrm{N}_{2}$ headspace, $\mathrm{H}_{2}$ evolution from propionate and butyrate occurred along the exponential phase of cell growth and was diminished with the onset of stationary phase. In the study of Sasikala et al. (1990), resting cells of $R$. sphaeroides O.U. 001 did not produce any $\mathrm{H}_{2}$ under a gas phase of pure $\mathrm{N}_{2}$. Our study using growing cells of $R$. sphaeroides KCTC 1434 therefore supports the fact that $\mathrm{H}_{2}$ is evolved as a side reaction during $\mathrm{N}_{2}$ fixation since during active cell growth, nitrogenase functions to provide precursors needed for protein biosynthesis. On the contrary, a continued accumulation of $\mathrm{H}_{2}$ was observed along the stationary phase of cell growth in Arpurged reactors. In many studies $\mathrm{H}_{2}$ evolution in $R$. sphaeroides starts in the mid- to late exponential growth phase (Koku et al., 2003: Eroglu et al., 1999; Tao et al., 2008; Golomysova et al., 2010). Using cells in stationary phase, Melnicki et al. (2008) reported $\mathrm{H}_{2}$ production in $R$. rubrum to be not strictly coupled with growth (Melnicki et al., 2008). Under active cell growth, organic substrates enter the tricarboxylic acid pathway cycle to provide necessary biosynthetic precursors and Nicotinamide Adenine Dinucleotide phosphate (NADH) for biomass synthesis. During this time, nitrogenase functions as a "safety valve" (Gest, 1972) that disposes excess electrons in cells, provided $\mathrm{N}_{2}$ fixation is absent. In the stationary phase where biosynthesis is minimal, most of the organic carbon is oxidized into $\mathrm{CO}_{2}$ and most of the extracted electrons are directed toward $\mathrm{H}_{2}$ production (Ormerod and Gest, 1962; Koku et al., 2002; Golomysova et al., 2010).

Despite the lower acid consumption rates, all $\mathrm{N}_{2}$ sparged reactors exhibited high final $\mathrm{pH}$ values (Table 3 ). The radical increase in $\mathrm{pH}$ could be explained by the nitrogenase-mediated $\mathrm{H}_{2}$ production via the reaction (Liang and Burris, 1988; Kars and Gunduz, 2010):

$$
\mathrm{N}_{2}+8 e^{-}+8 \mathrm{H}^{+}+16 \mathrm{ATP} \rightarrow 2 \mathrm{NH}_{3}+\mathrm{H}_{2}+16 \mathrm{ADP}+16 \mathrm{Pi}
$$

From this metabolic reaction, 2 moles of ammonia is produced per mole of $\mathrm{N}_{2}$ present. The dissolution of ammonia produces ammonium ion which could lead to the increase of $\mathrm{pH}$ in the medium. Additionally, $\mathrm{NH}_{3}$ has a substantial solubility in water (Sander, 2015), hence the rapid climb of $\mathrm{pH}$ once $\mathrm{N}_{2}$ fixation initiates. A similar account could be found in the study of Kim et al. (2012a) wherein an increase in $\mathrm{NH}_{4}{ }^{+}$concentration during photofermentative $\mathrm{H}_{2}$ production by $R$. sphaeroides KD131 resulted to an increased $\mathrm{pH}$ and $\mathrm{PHB}$ production. Nitrogenase operates at neutral $\mathrm{pH}$ with the highest activity at $\mathrm{pH}$ range of 6.5-7.5 (Peng et al., 1987). In our study, butyrate and propionate under Ar headspace had final $\mathrm{pH}$ values of 7.2 and 7.5. The presence of ammonia in nitrogen fixing environment renders a reversible inhibition on nitrogenase via the switch off effect. $\mathrm{H}_{2}$ production in $R$. sphaeroides M-19 was reported to be completely inhibited at ammonia concentrations higher than $2 \mathrm{mM}$ (Yokoi et al., 1998).

The $\mathrm{H}_{2}$ Production of $\mathrm{R}$. sphaeroides KCTC 1434 from Mixed VFAs using Ar and $N_{2}$ Headspace Gas

In their investigation of $\mathrm{H}_{2}$ production using $R$. sphaeroides OU 001 in mixed and individual acids, Uyar et al. (2009) also reported highest biomass accumulation in acetate. Using VFA mixtures, they made an acetate-rich bioreactor $(40 \mathrm{mM}$ acetate, $10 \mathrm{mM}$ butyrate and $5 \mathrm{mM}$ propionate) and a butyrate-rich bioreactor $(30 \mathrm{mM}$ butyrate, $10 \mathrm{~mm}$ acetate and $5 \mathrm{mM}$ acetate). They found out that among the three VFAs, acetate was consumed the fastest in the two bioreactors. They concluded that their strain preferred smaller substrates (2C in acetate versus $4 \mathrm{C}$ in butyrate). In this study, acetate was also consumed at a higher rate than propionate and butyrate. This consumption was however not attributed to $\mathrm{H}_{2}$ production since the use of acetate in individual acid experiments gave low $\mathrm{H}_{2}$ yields. In contrast to the results of Uyar et al. (2009) where SCE was improved with the use of mixed substrate, the results in this study showed lower SCE in mixed substrates. This decrease may have been due to acetate and the drastic pH evolution. Uyar et al. (2009) pointed out that they had to add high amount of buffer in acetatecontaining medium since this substrate had the tendency to increase the $\mathrm{pH}$ during the run. Several studies reported the negative effect of alkaline $\mathrm{pH}$ on nitrogenase activity and phototrophic $\mathrm{H}_{2}$ production. Peng et al. (1987) reported that the nitrogenase activity of $R$. sulfidophilus was highest at the $\mathrm{pH}$ range of 6.5-7.0 and decreased to zero at $\mathrm{pH}$ level of 8.0. Alkaline $\mathrm{pH}$ contributes more to the activity of hydrogenase while being detrimental to nitrogenase activity (Kim et al., 2012a). No pH adjustment was carried in this study and the buffer concentration used in MPB basal media (in the form of $\mathrm{KH}_{2} \mathrm{PO}_{4}$ and $\mathrm{K}_{2} \mathrm{HPO}_{4}$ ) was kept unchanged throughout the experiments.

\section{Comparison to other Literatures based on SCE}

The SCE is an indication of the specific $\mathrm{H}_{2}$ conversion yield of photofermentative bacteria per mole of substrate consumed. This is computed based on the actual $\mathrm{H}_{2}$ yield over the theoretical amount of $\mathrm{H}_{2}$ produced per mole of substrate. Comparing the results of the study with the existing literatures (Table 5), $R$. sphaeroides KCTC 1434 has the highest $\mathrm{H}_{2}$ conversion from propionate and butyrate based on SCE. 
Table 5. Substrate Conversion Efficiencies (SCE) in this study as compared with other literatures ${ }^{*}$

\begin{tabular}{|c|c|c|c|c|}
\hline \multirow[b]{2}{*}{ R. sphaeroides sp. } & \multicolumn{3}{|c|}{ SCE $(\%)$} & \multirow[b]{2}{*}{ Reference } \\
\hline & Acetate & Propionate & Butyrate & \\
\hline R. sphaeroides ZX-5 & 69.0 & 61.9 & 71.5 & Tao et al. (2008) \\
\hline R. sphaeroides OU 001 & 33.0 & 31 & 14.0 & Uyar et al. (2009) \\
\hline R. sphaeroides 131 & 17.5 & --- & 24.7 & Kim et al. (2011) \\
\hline R. sphaeroides KD 131 & 10.9 & --- & 12.3 & Kim et al. (2012a) \\
\hline R. sphaeroides NMBL-01 & 23.2 & --- & 14.1 & Pandey et al. (2012) \\
\hline R. sphaeroides $\mathrm{RV}$ & 98.0 & 78.3 & 81.6 & Han et al. (2012) \\
\hline R. sphaeroides CNT $2 \mathrm{~A}$ & 52.5 & --- & 29.0 & Subudhi et al. (2016) \\
\hline R. sphaeroides KCTC 1434 (Ar-headspace) & 1.8 & 87.2 & 88.4 & This study \\
\hline R. sphaeroides KCTC 1434 ( $\mathrm{N}_{2}$-headspace) & 1.8 & 7.1 & 12.6 & This study \\
\hline
\end{tabular}

${ }^{*}$ All studies from literature were kept under Ar-headspace

While the study of Han et al. (2012) reported the highest SCE on acetate and Tao et al. (2008) the highest on butyrate, only $R$. sphaeroides KCTC 1434 showed very low SCE for acetate but high SCE for propionate and butyrate. It can therefore be deduced that the strain used in the study prefer acetate for biomass formation while propionate and butyrate are directly converted to $\mathrm{H}_{2}$. Once measures to control the negative effect of acetate in the culture media are taken, the strain can be a good coculture candidate for an enhanced $\mathrm{H}_{2}$ production using mixed substrate such as VFAs. Based on SCE, it has been observed that most of the $\mathrm{H}_{2}$-producing microorganism prefer acetate in mixed acid fermentation (Uyar et al., 2009; Lo et al., 2011; Han et al., 2012).

\section{Conclusion}

$\mathrm{H}_{2}$ production of $R$. sphaeroides KCTC 1434 was investigated under $\mathrm{Ar}$ and $\mathrm{N}_{2}$ headspace. Our results indicated that unlike most PNSB, our strain utilizes propionate and butyrate better than acetate for $\mathrm{H}_{2}$ production under Ar headspace. The use of acetate for $\mathrm{H}_{2}$ generation is accompanied with high biomass yield and high $\mathrm{pH}$ increase in both headspace gases. $\mathrm{N}_{2}$ inhibited $\mathrm{H}_{2}$ productivity and the minimal amount of $\mathrm{H}_{2}$ evolved was associated with cell growth. $\mathrm{N}_{2-}$ fixation during $\mathrm{H}_{2}$ production leads to an increased biomass yield and radical $\mathrm{pH}$ rise. $\mathrm{H}_{2}$ generation increased acid consumption rate. The utilization of mixed acid substrate in photofermentative $\mathrm{H}_{2}$ production by $R$. sphaeroides KCTC 1434 necessitates refinement of culture parameters such as $\mathrm{pH}$ control, illumination and other operating conditions.

\section{Acknowledgement}

This research was supported by the Basic Science Research Program through the National Research Foundation of Korea (NRF) funded by the Ministry of Education, Science and Technology (2010-0009660). $\mathrm{We}$ are also thankful to the University of the Philippines Los Baños, Office of the Vice Chancellor for Research and Extension, for the Publication Grant Program of 2016.

\section{References}

Amrouche, D.A., N. Abdi, H. Lounici and N. Mameri, 2011. Effect of physico-chemical parameters on biohydrogen production and growth characteristics by batch culture of Rhodobacter sphaeroides CIP 60.6. Applied Energy, 88: 2130-2135.

DOI: $10.1016 /$ j.apenergy.2010.12.044

Argun, H., F. Kargi and I.K. Kapdan, 2008. Light fermentation of dark fermentation effluent for biohydrogen production by different Rhodobacter species at different initial volatile fatty acid. Int. J. Hydrogen Energy, 33: 7405-7412.

DOI: 10.1016/j.ijhydene.2008.09.059

Balat, M., E. Kirtay and H. Balat, 2009. Main routes for the thermo-conversion of biomass into fuels and chemicals. Part 2: Gasification systems. Energy Convers. Manage., 50: 3158-68.

DOI: $10.1016 /$ j.enconman.2009.08.013

Chookaew, T., S. O-Thong and P. Prasertsan, 2015. Biohydrogen production from crude glycerol by twostage of dark and photo fermentation. Int. J. Hydrogen Energy, 40: 7433-7438. DOI: 10.1016/j.ijhydene.2015.02.133

Das, D. and N. Veziroglu, 2001. Hydrogen production by biological processes: A survey of literature. Int. J. Hydrogen Energy, 26: 13-28. DOI: 10.1016/S0360-3199(00)00058-6

Erb, T., I. Berg, V. Brecht, M. Muller and G. Fuchs et al., 2007. Synthesis of $\mathrm{C}_{5}$-dicarboxylic acids from $\mathrm{C}_{2}$ units involving crotonyl-CoA carboxylase/reductase: The ethylmalonyl-CoA pathway. Proc. Nat. Acad. Sci. USA, 104: 10631-10636. DOI: 10.1073/pnas.0702791104

Eroglu, I., K. Aslan, U. Gunduz, M. Yucel and L. Turker, 1999. Substrate consumption rates for hydrogen production by Rhodobacter sphaeroides in a column photobioreactor. J. Biotechnol., 70: 103-113. DOI: $10.1016 / \mathrm{S} 0168-1656(99) 00064-4$ 
Fang, H. and H. Yu, 2002. Mesophilic acidification of gelatinaceous wastewater. J. Biotechnol., 93: 99-108. DOI: $10.1016 / \mathrm{S} 0168-1656(01) 00397-2$

Fang, H.P., H. Liu and T. Zhang, 2005. Phototrophic hydrogen production from acetate and butyrate in wastewater. Int. J. Hydrogen Energy, 30: 785-793. DOI: 10.1016/j.ijhydene.2004.12.010

Gest, H., 1972. Energy conversion and generation of reducing power in bacterial photosynthesis. Adv. Micro Physiol., 7: 243-282.

DOI: $10.1016 / \mathrm{S} 0065-2911(08) 60080-6$

Golden, J.S. and R.B. HAndfield, 2014. Why biobased? Opportunities in the emerging bioeconomy. US Department of Agriculture. Washington, DC.

Golomysova, A., M. Gomelsky and P. Ivanov, 2010. Flux balance analysis of photoheterotrophic growth of purple nonsulfur bacteria relevant to biohydrogen production. Int. J. Hydrogen Energy, 35: 12751-12760. DOI: 10.1016/j.ijhydene.2010.08.133

Han, H., B. Liu, H. Yang and J. Shen, 2012. Effect of carbon sources on the photobiological production of hydrogen using Rhodobacter sphaeroides RV. Int. J. Hydrogen Energy, 37: 12167-12174.

DOI: 10.1016/j.ijhydene.2012.03.134

Hustede, E., A. Steinbuchel and H. Schlegel, 1993. Relationship between the photoproduction of hydrogen and the accumulation of PHB in nonsulphur purple bacteria. Applied Microbiol. Biot., 39: 87-93. DOI: 10.1007/BF00166854

Kapdan, I.K. and F. Kargi, 2006. Bio-hydrogen production from waste materials. Enzyme Microbial Technol., 38: 569-582. DOI: 10.1016/j.enzmictec.2005.09.015

Kars, G. and U. Gunduz, 2010. Towards a super $\mathrm{H}_{2}$ producer: Improvements in photofermentative biohydrogen production by genetic manipulations. Int. J. Hydrogen Energy, 35: 6646-6656. DOI: 10.1016/j.ijhydene.2010.04.037

Khatipov, E., M. Miyake, J. Miyake and Y. Asada, 1998. Accumulation of poly- $\beta$-hydroxybutyrate by Rhodobacter sphaeroides on various carbon and nitrogen substrates. FEMS Microbiol. Lett., 162: 39-45. DOI: 10.1016/S0378-1097(98)00099-8

Kim, M.S., D.H. Kim, H.N. Son, L.N. Ten and J.K. Lee, 2011. Enhancing photo-fermentative hydrogen production by Rhodobacter sphaeroides KD131 and its PHB synthase deleted-mutant from acetate and butyrate. Int. J. Hydrogen Energy, 36: 13964-13971. DOI: 10.1016/j.ijhydene.2011.03.099

Kim. M.S., D.H. Kim and J. Cha, 2012a. Culture conditions affecting $\mathrm{H}_{2}$ production by phototrophic bacterium Rhodobacter sphaeroides KD131. Int. J. Hydrogen Energy, 37: 14055-14061.

DOI: $10.1016 / j$.ijhydene.2012.06.085
Kim, H., S. Moon, A. Abug, S.C. Choi and R. Zhang et al., 2012b. Effect of fermentation conditions on biohydrogen production from lipid-rich food material. Int. J. Hydrogen Energy, 31: 15062-15069. DOI: 10.1016/j.ijhydene.2012.07.104

Kobayashi, J., K. Yoshimune, T. Komoriya and H. Kohno, 2011. Efficient hydrogen production from acetate through isolated Rhodobacter sphaeroides. J. Biosci. Bioeng., 6: 602-605. DOI: 10.1016/j.jbiosc.2011.08.008

Koku, H., I. Eroglu, U. Gunduz, M. Yucel and L. Turker, 2002. Aspects of the metabolism of hydrogen production by Rhodobacter sphaeroides. Int. J. Hydrogen Energy, 27: 1315-1329.

DOI: 10.1016/S0360-3199(02)00127-1

Koku, H., I. Eroglu, U. Gunduz, M. Yucel and L. Turker, 2003. Kinetics of biological hydrogen production by the photosynthetic bacterium Rhodobacter sphaeroides O.U. 001. Int. J. Hydrogen Energy, 28: 381-388. DOI: 10.1016/S0360-3199(02)00080-0

Laurinavichene, T.V., B.F. Belokopytov, K.S. Laurinavichius, D.N. Tekucheva and M. Seibert et al., 2010. Towards the integration of dark- and photofermentative waste treatment. 3. Potato as substrate for sequential dark fermentation and light-driven $\mathrm{H}_{2}$ production. Int. J. Hydrogen Energy, 35: 8536-8543. DOI: $10.1016 /$ j.ijhydene.2010.02.063

Lee, D.H., 2016. Cost-benefit analysis, LCOE and evaluation of financial feasibility of full commercialization of biohydrogen. Int. J. Hydrogen Energy, 41: 4347-4357.

DOI: $10.1016 /$ j.ijhydene.2015.09.071

Lee, H.J., J.Y. Park, C.H. Han, S.T. Chang and Y.H. Kim et al., 2011. Blue LED and succinic acid enhance the growth of Rhodobacter sphaeroides. World J. Microbiol. Biotechnol., 27: 189-192. DOI: $10.1007 / \mathrm{s} 11274-010-0434-3$

Liang, J. and H.R. Burris, 1988. Hydrogen burst associated with nitrogenase-catalyzed reactions. Proc. Nat. Acad. Sci. USA, 85: 9446-50. DOI: 10.1073/pnas.85.24.9446

Liu, B., N. Ren, J. Ding, G. Xie and G. Cao, 2009. Enhanced photo- $\mathrm{H}_{2}$ production of $R$. faecalis RLD53 by separation of $\mathrm{CO}_{2}$ from reaction system. Bioresource Tech., 100: 1501-1504.

DOI: 10.1016/j.biortech.2008.08.027

Lo, Y.S., C.H. Chen, C.M. Lee and J.S. Chang, 2011. Photo fermentative hydrogen production using dominant components (acetate, lactate and butyrate) in dark fermentation effluents. Int. J. Hydrogen Energy, 36: 14059-14068.

DOI: $10.1016 /$ j.ijhydene.2011.04.148

Madigan, M., S. Cos and R. Stegeman, 1984. Nitrogen fixation and nitrogenase activities in members of the family Rhodospirillaceae. J. Bacteriol., 157: 73-78. 
Melnicki, M., L. Bianchi, R. De Philippis and A. Melis, 2008. Hydrogen production during stationary phase in purple photosynthetic bacteria. Int. J. Hydrogen Energy, 33: 6525-6534.

DOI: 10.1016/j.ijhydene.2008.08.041

Nath, K. and D. Das, 2004. Biohydorgen production as a potential energy source-present state-of-art. J. Scientific Indust. Res., 63: 729-738

Ormerod, J. and H. Gest, 1962. Hydrogen photosynthesis and alternative metabolic pathways in photosynthetic bacteria. Bacteriol. Rev., 26: 51-66.

Pandey, A., N. Srivastava and P. Sinha, 2012. Optimization of hydrogen production by Rhodobacter sphaeroides NMBL-01. Biomass Bioenerg., 37: 251-256.

DOI: 10.1016/j.biombioe.2011.12.005

Pan, J., R. Zhang, H.M. El-Mashad, H. Sun and Y. Ying, 2008. Effect of food to microorganism ratio on biohydrogen production from food waste via anaerobic fermentation. Int. J. Hydrogen Energy, 33: 6968-6975. DOI: 10.1016/j.ijhydene.2008.07.130

Peng, Y., P. Steven, P. De Vos and J. De Ley, 1987. Relation between $\mathrm{pH}$, hydrogenase and nitrogenase activity, $\mathrm{NH}_{4}^{+}$concentration and hydrogen production in culutures of Rhodobacter sulfidophilus. J. Gen. Microbiol., 133: 1243-1247.

Sander, R., 2015. Compilation of Henry's law constants (Version 4.0) for water as solvent. Atmos. Chem. Phys., 15: 4399-4981. DOI: $10.5194 / \mathrm{acp}-15-4399-2015$

Sasikala, K., C.H. Ramana, R. Rao and M. Subrahmanyam, 1990. Effect of gas phase on the photoproduction of hydrogen and substrate conversion efficiency in the photosynthetic bacterium Rhodobacter sphaeroides O.U. 001. Int. J. Hydrogen Energy, 15: 795-797. DOI: 10.1016/0360-3199(90)90015-Q

Shi, X.Y. and H.Q. Yu, 2006. Continuous production of hydrogen from mixed volatile fatty acids with Rhodopseudomonas capsulata. Int. J. Hydrogen Energy, 31: 1641-1647.

DOI: $10.1016 /$ j.ijhydene.2005.12.008
Su, H., J. Cheng, J. Zhou, W. Song and K. Cen, 2009. Combination of dark- and photo-fermentation to enhance hydrogen production and energy conversion efficiency. Int. J. Hydrogen Energy, 34: 8846-8853. DOI: 10.1016/j.ijhydene.2009.09.001

Subudhi, S., S.K. Mogal, N.R. Kumar, T. Nayak and B. Lal et al., 2016. Photo fermentative hydrogen production by a new strain; Rhodobacter sphaeroides CNT 2A, isolated from pond sediment. Int. J. Hydrogen Energy, 41: 13979-13985.

DOI: 10.1016/j.ijhydene.2016.06.255

Sweet, J.W. and R.H. Burris, 1981. Inhibition of nitrogenase activity by $\mathrm{NH}_{4}^{+}$in Rhodospirillum rubrum. J. Bacteriol., 145: 824-831.

Tao, T., Y. He, Y. Wu, F. Liu and X. Li et al., 2008. Characteristics of a new photosynthetic bacterial strain for hydrogen production and its application in wastewater treatment. Int. J. Hydrogen Energy, 33: 963-973. DOI: 10.1016/j.ijhydene.2007.11.021

Uyar, B., I. Eroglu, M. Yucel and G. Ufuk, 2009. Photofermentative hydrogen production from volatile fatty acids present in dark fermentation effluents. Int. J. Hydrogen Energy, 34: 4517-4523. DOI: 10.1016/j.ijhydene.2008.07.057

$\mathrm{Wu}$, S., S. Liou and C. Lee, 2012. Correlation between bio-hydrogen production and polyhydroxybutyrate (PHB) synthesis by Rhodopseudomonas palustris WP3-5. Bioresource Technol., 113: 44-50. DOI: 10.1016/j.biortech.2012.01.090

Yiilmaz, L.S., S. Wayne, W.S. Kontur, A. Sanders and U. Sohmen et al., 2010. Electron partitioning during light- and nutrient-powered hydrogen production by Rhodobacter sphaeroides. Bioenerg. Res., 3: 55-66. DOI: $10.1007 / \mathrm{s} 12155-009-9072-8$

Yokoi, H., S. Mori, J. Hirose, S. Hayashi and Y. Takasaki, 1998. $\mathrm{H}_{2}$ production from starch by a mixed culture of Clostridium butyricum and Rhodobacter sp. M[h]19. Biotechnol Lett., 20: 895-899.

DOI: $10.1023 / \mathrm{A}: 1005327912678$ 